\title{
Life cycle assessment (LCA) kegiatan bank sampah di pedesaan (Bank Sampah Asoka Berseri, Desa Sokosari, Tuban)
}

\author{
T. T. Anasstasia ${ }^{*}$, M. M. Azis ${ }^{2}$ \\ ${ }_{1}^{1}$ Jurusan Teknik Lingkungan, Fakultas Teknologi Mineral, Universitas Pembangunan Nasional Veteran \\ Yogyakarta, Yogyakarta, Indonesia \\ 2Departemen Teknik Kimia, Fakultas Teknik, Universitas Gadjah Mada, Yogyakarta, Indonesia
}

\begin{abstract}
Abstrak.
Life Cycle Assessment (LCA) adalah salah satu cara yang dapat digunakan untuk mengevaluasi sistem pengelolaan sampah berdasarkan nilai potensi dampak yang dihasilkan. Bank Sampah Asoka Berseri di Kabupaten Tuban merupakan salah satu contoh unit pengolah sampah yang bertujuan untuk mengurangi potensi dampak dari timbulan sampah secara kualitas maupun kuantitas di wilayah pedesaan. Tujuan studi ini adalah menghitung dan mengevaluasi potensi dampak lingkungan yang dihasilkan dari program bank sampah, kemudian dibandingkan dengan penanganan sampah konvensional yang dilakukan oleh masyarakat. Metode yang digunakan berdasarkan CML Baseline v4.4 dan 14000 standar ISO, meliputi goal and scope, life cycle inventory (LCI), life cycle impact assessment (LCIA) dan interpretasi. Simulasi LCA dilakukan dengan Software OpenLCA untuk menghitung nilai potensi dampak dari setiap kilogram sampah yang dihasilkan. Berdasarkan hasil simulasi, setiap $1 \mathrm{~kg}$ sampah yang dikelola oleh bank sampah menghasilkan potensi dampak pemanasan global lebih rendah $\left(6,395 \mathrm{~kg} \mathrm{CO}_{2}\right.$ eq.) dibandingkan dengan penimbunan $\left(13,057 \mathrm{~kg} \mathrm{CO}_{2}\right.$ eq. $)$ dan pembakaran $\left(10,850 \mathrm{~kg} \mathrm{CO}_{2}\right.$ eq.). Pengolahan sampah lebih lanjut menjadi RDF dan kompos di bank sampah berpotensi menghasilkan dampak lingkungan lebih rendah dan menambah pendapatan masyarakat.
\end{abstract}

\begin{abstract}
.
Life Cycle Assessment (LCA) is a method that can be used to evaluate the waste management system based on the potential impact produced. The Asoka Berseri Waste Bank in Tuban Regency is an example of a waste processing unit that aims to reduce the possible effects of waste generation both in quality and quantity in rural areas. This study aimed to calculate and evaluate the potential environmental impacts from the waste bank, then compared it with conventional waste management carried out by the community. The method used was based on CML Baseline v4.4 and ISO 14000 standards, including goal and scope, life cycle inventory (LCI), life cycle impact assessment (LCIA) and interpretation. The LCA simulation was carried out with the OpenLCA software to calculate the value of the potential impact of each kilogram of waste produced. Based on the simulation results, every $1 \mathrm{~kg}$ of waste managed by the waste bank produced a lower potential global warming impact (6.395 kg $\mathrm{CO}_{2}$ eq.) than open dumping (13.057 $\mathrm{kg} \mathrm{CO}$ eq.) and open burning $(10.850 \mathrm{~kg} \mathrm{CO} 2$ eq.). Further processing of solid waste into RDF and compost at the Waste Bank present a lower potential environmental impact and increase community income.
\end{abstract}

Keywords: LCA, waste bank, rural area

Kata kunci: LCA, bank sampah, pedesaan

\section{PENDAHULUAN}

Keterbatasan pengelolaan sampah di Kabupaten Tuban khususnya di wilayah pedesaan menjadikan sistem pengelolaan sampah menjadi tidak terkendali. Kesadaran dan pengetahuan masyarakat dalam memilah dan mengelola sampah yang rendah menyebabkan penimbunan sampah secara terbuka (open dumping) menjadi tumpuan sistem pengelolaan sampah. Menurut Luong et al. (2013) dan Abbas et al. (2017), open dumping terjadi akibat rendahnya tingkat pengumpulan, pemilahan, pendanaan dan kualitas sumber daya manusia dalam pengelolaan sampah. Pengelolaan sampah di Kabupaten Tuban masih bertumpu pada Tempat Pembuangan Akhir (TPA) Gunung

${ }^{*}$ Korespondensi Penulis

Email : tiara.anasstasia@upnyk.ac.id 
Panggung. Total timbulan sampah yang dibuang ke TPA Gunung Panggung mencapai 50 ton/hari dengan komposisi berupa sampah makanan $(55,58 \%)$, sampah kebun $(19,11 \%)$, sampah plastik $(9,68 \%)$, sampah kertas $(5,02 \%)$, sampah kayu $(0,06 \%)$, sampah kain/tekstil $(1,55 \%)$, sampah logam $(0,08 \%)$, sampah kaca/gelas (3,61\%) dan sampah diapers (5,30\%) (Ummatin et al. 2019).

Desa Sokosari merupakan salah satu wilayah di Kabupaten Tuban yang memiliki jumlah penduduk sebanyak 7.794 jiwa (2.445 KK) dan tergolong sebagai wilayah perdesaan (BPS Kabupaten Tuban 2019). Penanganan sampah di Desa Sokosari masih didominasi oleh penimbunan sampah secara terbuka (Gambar 1). Pemerintah desa telah menyediakan lahan untuk tempat pembuangan sampah, hanya saja masih digunakan secara terbatas untuk penampungan sampah dari pasar, sapuan jalan dan beberapa rumah penduduk. Masyarakat pedesaan umumnya hanya menumpuk dan membakar sampah di lahan kosong atau pekarangan rumah, bahkan beberapa memanfaatkan sampah organik dari sisa dapur dan sisa makanan untuk pakan ternak seperti sapi, kambing, ayam, bebek, dsb. Selain itu, masih banyak sampah yang teronggok di sungai, saluran irigasi dan dibakar begitu saja. Sampah yang ditimbun secara terbuka berpotensi menghasilkan gas-gas hasil dekomposisi seperti $\mathrm{CH}_{4}, \mathrm{H}_{2} \mathrm{~S}$ dan $\mathrm{CO}_{2}$ yang dapat terlepas ke atmosfer (Bailie et al. 1999; Tchobanoglous and Kreith 2019). Sampah yang dibakar secara terbuka berpotensi melepaskan gasgas seperti $\mathrm{CO}_{2}, \mathrm{CH}_{4}, \mathrm{CO}, \mathrm{SO}_{x}$, particulate matter (PM), dsb. (EPA 2001).

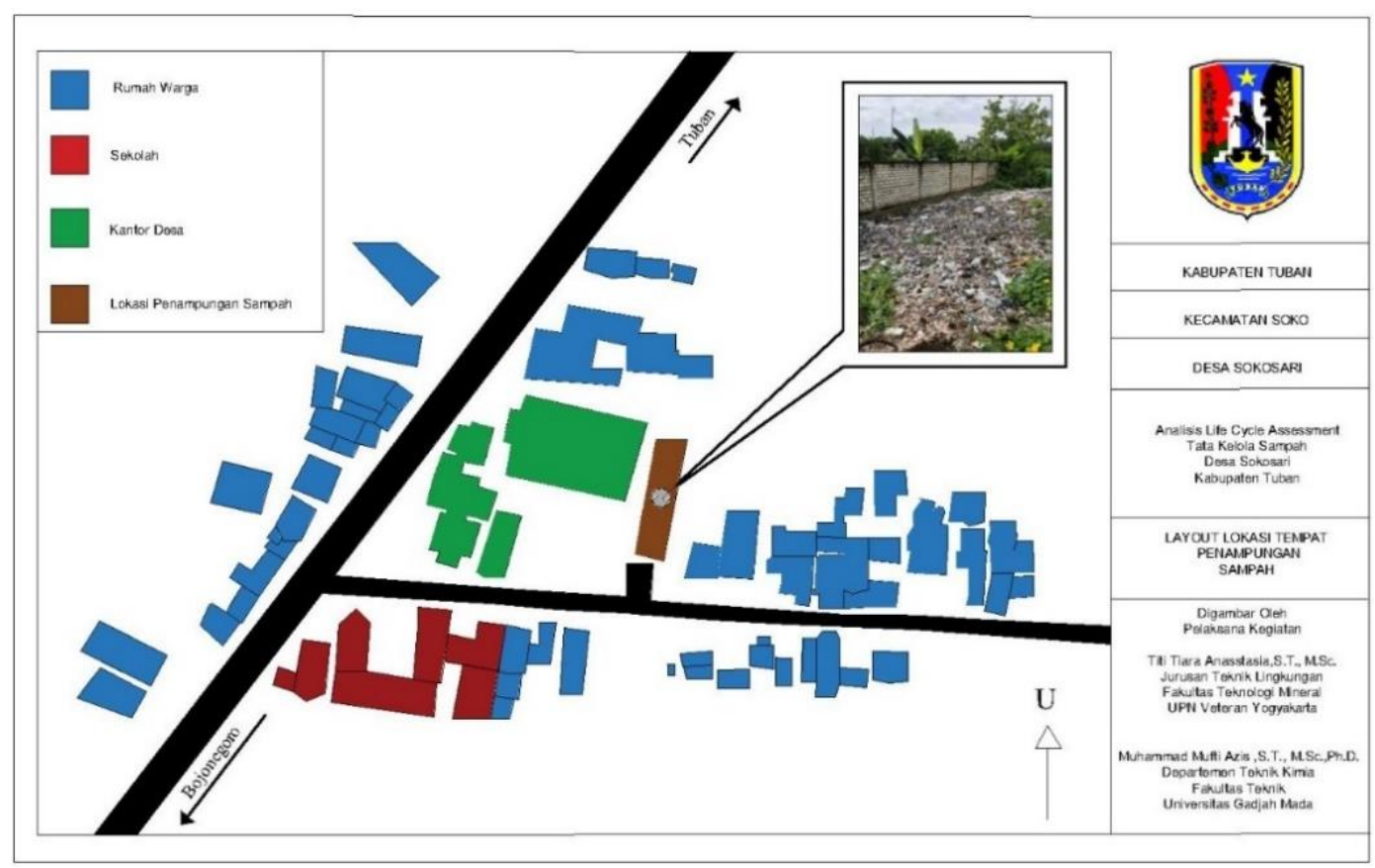

Gambar 1. Tempat penimbunan sampah terbuka di Desa Sokosari. 
Sistem pengelolaan sampah yang terbatas menggambarkan rendahnya perhatian pemerintah terhadap kondisi lingkungan dan sanitasi masyarakat. Pemerintah perlu menyediakan fasilitas/infrastruktur yang memadai dan melakukan pendekatan simultan dari berbagai aspek untuk menentukan sistem pengelolaan yang berkelanjutan. Bank sampah merupakan salah satu solusi yang dapat diterapkan dalam sistem pengelolaan sampah. Bank sampah memiliki konsep social engineering atau berbasiskan pada masyarakat untuk tujuan mengelola dan mengurangi sampah (Wijayanti and Suryani 2015). Bank sampah dapat meningkatkan kesadaran masyarakat dalam memilah sampah (Wulandari et al. 2017; Pambudi et al. 2020) dan meningkatkan kesejahteraan masyarakat melalui hasil penjualan sampah yang telah dipilah (Suardi et al. 2018). Beberapa penelitian mengklaim bahwa keberadaan bank sampah dapat mereduksi sekitar 0,13\% sampah yang dibuang ke TPA (Budihardjo et al. 2019; Warmadewanthi and Haqq 2019). Hal ini berpotensi untuk menurunkan lindi sampah yang dihasilkan dari kandungan air pada sampah dan presipitasi yang melewati sampah yang ditimbun (Komilis and Athiniotou 2014). Lindi sampah biasanya berbau tidak sedap dan mengandung konstituen pencemar (COD, BOD, TOC dan nitrat) dalam konsentrasi tinggi (Tchobanoglous and Kreith 2019).

Desa Sokosari merupakan salah satu wilayah di Kabupaten Tuban yang telah menerapkan bank sampah. Bank sampah di desa ini diberi nama Bank Sampah Asoka Berseri yang telah ada sejak tahun 2016. Pada studi ini, Bank Sampah Asoka Berseri dijadikan sebagai percontohan dalam proses penelitian. Penelitian ini menunjukkan Life Cycle Assessment (LCA) sebagai salah satu tool yang dapat digunakan untuk menghitung dan menganalisis potensi dampak lingkungan dari pengelolaan sampah, khususnya untuk mengetahui nilai potensi pemanasan global apabila bank sampah diterapkan di lingkungan pedesaan. LCA sudah diterapkan untuk menghitung potensi dampak pada beberapa sistem pengelolaan sampah dan untuk pemilihan sistem pengelolaan sampah yang paling ramah lingkungan (Liamsanguan and Gheewala 2008; Abeliotis 2011; Bernstad et al. 2011). Hasil interpretasi dan rekomendasi dari simulasi LCA diharapkan mampu memberikan gambaran dan masukkan dalam meningkatkan tata kelola sampah yang berkelanjutan di wilayah pedesaan.

\section{METODOLOGI}

\subsection{Lokasi kajian dan waktu penelitian}

Lokasi penelitian adalah rumah warga pelanggan bank sampah (76'57,97"LS; 111 $\left.{ }^{\circ} 56^{\prime} 46.03^{\prime \prime B T}\right)$ dan kantor Bank Sampah Asoka Berseri (76'47,31"LS; $\left.111^{\circ} 56^{\prime} 53,26^{\prime \prime B T}\right)$ yang terletak di Desa Sokosari, Kecamatan Soko, Kabupaten Tuban, Provinsi Jawa Timur. Inventarisasi data sampah dilakukan pada Januari-Maret 2020. 


\subsection{Prosedur analisis data}

Studi ini dilaksanakan dengan tahapan observasi, studi literatur, analisis data dan penarikan kesimpulan. Metode analisis data dilaksanakan berdasarkan CML Baseline v4.4 dan standar seri ISO 14000 tentang analisis Life Cycle Assessment yang meliputi goal and scope definition, life cycle inventory (LCI), life cycle impact assessment (LCIA) dan interpretasi. Perhitungan LCA dilakukan dengan software OpenLCA menggunakan data inventory yang diperoleh dari hasil observasi dan perhitungan.

\subsubsection{Goal and scope definition}

Goal dari penelitian ini adalah menilai dan membandingkan potensi dampak lingkungan dari pengelolaan sampah sebelum dan sesudah diterapkannya Bank Sampah Asoka Berseri. Terdapat beberapa skenario yang dibandingkan yaitu:

- Skenario 1 : Penimbunan seluruh sampah di lahan penampungan sampah secara terbuka. Luas lahan penampungan sampah 484,84 $\mathrm{m}^{2}$.

- Skenario 2 : Pembakaran seluruh sampah secara terbuka.

- Skenario 3 : Sampah layak jual (kantong plastik, plastik keras, kertas, karet, logam) dikelola oleh bank sampah dan sampah tidak layak jual (sisa dapur, sapuan jalan dan sampah taman/pekarangan) ditimbun di lahan penampungan secara terbuka.

Scope dari penelitian yaitu gate to gate, mulai dari sampah dihasilkan sampai akhir perlakukan sampah. Unit fungsi sebagai basis perhitungan dalam studi LCA ini adalah setiap $1 \mathrm{~kg}$ sampah domestik yang dikelola. System Boundary atau batasan sistem penelitian ini sesuai pada Gambar 2 .

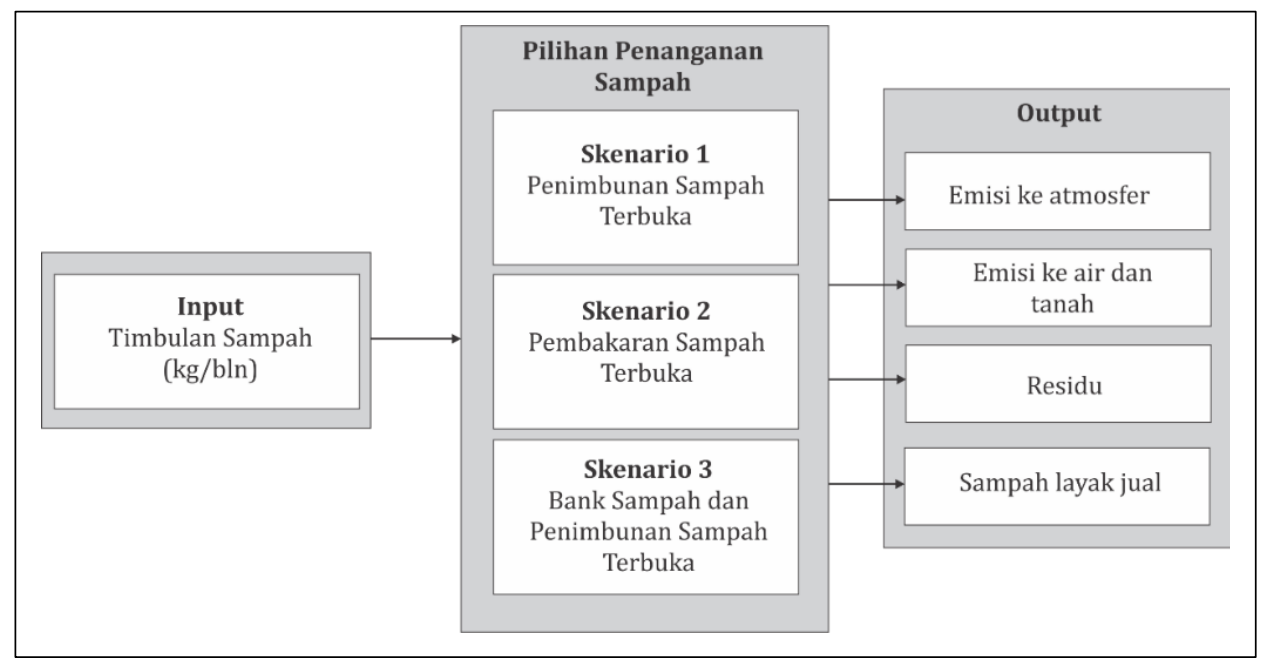

Gambar 2. Batasan sistem penelitian. 


\subsubsection{Life cycle inventory (LCI)}

Tahap LCI ditujukan untuk membangun model sistem yang berupa model aliran dari sistem teknis dengan jenis batas sistem tertentu. Data yang digunakan terdiri dari data primer dan sekunder. Pemodelan sistem menggunakan software OpenLCA dan database Ecoinvent.

a. Data input

Estimasi jumlah timbulan sampah dan komposisi sampah ditentukan berdasarkan SNI 19-3964-1994 dengan metode purposive sampling. Potensi timbulan sampah di Desa Sokosari rata-rata sebesar 1,52-1,68 kg/hari/KK dengan estimasi total timbulan sampah adalah 3,27 ton/hari. Komposisi sampah terdiri dari dua jenis yaitu sampah tidak layak jual atau STJ $(74,7 \%)$ dan sampah layak jual atau SLJ $(25,3 \%)$. Sampah layak jual mencakup kantong plastik, gelas dan botol plastik, ember plastik, kertas, kardus, buku, glangsing, kaleng, besi, karet dan kain bekas. Sampah tidak layak jual meliputi sampah sisa makanan, sampah sisa dapur dan sampah pekarangan. Data komposisi sampah selama tahun 2018-2019 di Bank Sampah Asoka Berseri disajikan pada Gambar 3, sedangkan karakteristik sampah di Desa Sokosari beserta nilai ultimate sampah yang diperoleh dari Phyllis2 (2020) disampaikan melalui Tabel 1.

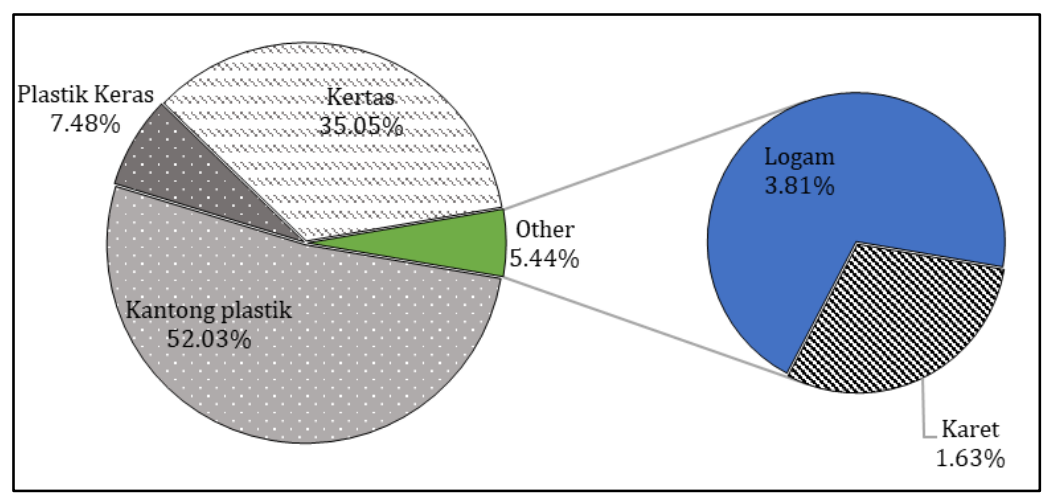

Gambar 3. Komposisi sampah di Bank Sampah Asoka Berseri.

Tabel 1. Karakteristik sampah di Desa Sokosari, Kabupaten Tuban.

\begin{tabular}{|c|c|c|c|c|c|c|c|c|}
\hline \multirow{2}{*}{ Jenis sampah } & \multirow{2}{*}{$\begin{array}{c}\text { Berat } \\
\text { basah } \\
(\mathrm{kg})\end{array}$} & \multirow{2}{*}{$\begin{array}{c}\text { Berat } \\
\text { kering } \\
(\mathrm{kg})\end{array}$} & \multicolumn{6}{|c|}{ Ultimate composition-dry basis (kg)* } \\
\hline & & & $\mathrm{C}$ & $\mathrm{H}$ & $\mathrm{N}$ & 0 & $S$ & Ash \\
\hline Organik & 926,58 & 426,22 & 179,40 & 23,14 & 8,01 & 133,15 & 1,75 & 80,77 \\
\hline Kantong plastik & 163,29 & 132,10 & 102,25 & 17,04 & 0,13 & 2,25 & 0,13 & 10,30 \\
\hline Botol plastik & 23,46 & 22,61 & 15,49 & 1,81 & 0,04 & 4,95 & 0,02 & 0,31 \\
\hline Kertas & 109,98 & 78,42 & 33,13 & 4,99 & 0,20 & 31,85 & 0,08 & 8,17 \\
\hline Karet & 5,13 & 5,10 & 1,29 & 0,13 & 0,01 & 1,27 & 0,01 & 2,40 \\
\hline Logam & 11,96 & ND & ND & ND & ND & ND & ND & ND \\
\hline Total & $1.235,27$ & 692,98 & 364,35 & 50,02 & 8,37 & 168,37 & 2,00 & 94,26 \\
\hline
\end{tabular}




\section{b. Data output}

Neraca massa proses pembakaran sampah mengikuti Persamaan 1. MSW (kg) adalah jumlah sampah yang dibakar. Estimasi jumlah emisi yang dilepaskan ke atmosfer ditentukan dengan Persamaan 2 dan Persamaan 3, serta faktor emisi menggunakan standar Intergovernmental Panel on Climate Change (IPCC 2006) dan CML Baseline. Residu sisa pembakaran diperoleh dari kadar abu (kg) dalam sampah.

$\mathrm{MSW}_{b}=$ Emission $_{i, j}+$ Residue

Emission $=\Sigma_{i}\left(l W_{i} \times E F_{i}\right) \times 10^{-6}$

Keterangan:

$\mathrm{IW}_{\mathrm{i}}=$ Jumlah sampah yang dibakar $(\mathrm{Gg} / \mathrm{th})$

$\mathrm{EF}_{\mathrm{i}}=$ Faktor emisi untuk setiap jenis sampah (kg/Gg sampah)

$10^{-6}=$ Konversi dari kilogram ke gigagram

$\mathrm{i} \quad=$ Kategori atau jenis sampah yang dibakar

$\mathrm{CO}_{2}$ Emission $=M S W \times \Sigma_{j}\left(W F_{j} x d m_{j} x C F_{j} x F C F_{j} x O F_{j}\right) \times 44 / 12$

Keterangan:

$\mathrm{CO}_{2}$ Emission = Emisi karbon dioksida (Gg/tahun)

$\mathrm{WF}_{\mathrm{j}} \quad=$ Fraksi jenis sampah (dalam berat basah)

$\mathrm{dm}_{\mathrm{j}} \quad=$ Kandungan bahan kering di dalam komponen

$\mathrm{CF}_{\mathrm{j}} \quad=$ Fraksi karbon dalam bahan kering

$\mathrm{FCF}_{\mathrm{j}} \quad=$ Fraksi karbon fosil dalam total komponen karbon

$\mathrm{OF}_{\mathrm{j}} \quad=$ Faktor oksidasi

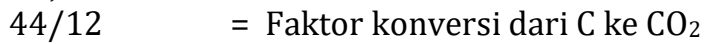

$\mathrm{J}=$ Komponen sampah

Berdasarkan Gambar 2 dan Tabel 1, diketahui bahwa sampah kertas dan organik merupakan sampah yang cepat terurai apabila ditimbun di lahan terbuka. Gas dari proses dekomposisi sampah Skenario 1 ditentukan berdasarkan formula $\mathrm{C}_{485,39} \mathrm{H}_{792,44} \mathrm{O}_{192,28} \mathrm{~N}_{8,37} \mathrm{~S}$. Untuk Skenario 3, penimbunan sampah organik menggunakan formula $\mathrm{C}_{274,04} \mathrm{H}_{420,40} \mathrm{O}_{174,36} \mathrm{~N}_{9,19} \mathrm{~S}$. Estimasi gas yang dihasilkan ditentukan dengan Persamaan 4 (Achinas and Euverink 2016).

$\mathrm{C}_{\mathrm{a}} \mathrm{H}_{\mathrm{b}} \mathrm{O}_{\mathrm{c}} \mathrm{N}_{\mathrm{d}} \mathrm{S}_{\mathrm{e}}+\left(\mathrm{a}-\frac{\mathrm{b}}{4}-\frac{\mathrm{c}}{2}+\frac{3 \mathrm{~d}}{4}+\frac{\mathrm{e}}{2}\right) \mathrm{H}_{2} \mathrm{O} \rightarrow\left(\frac{\mathrm{a}}{2}+\frac{\mathrm{b}}{8}-\frac{\mathrm{c}}{4}-\frac{3 \mathrm{~d}}{8}-\frac{\mathrm{e}}{4}\right) \mathrm{CH}_{4}+\left(\frac{\mathrm{a}}{2}-\frac{\mathrm{b}}{8}+\frac{\mathrm{c}}{4}+\frac{3 \mathrm{~d}}{8}+\frac{\mathrm{e}}{4}\right) \mathrm{CO}_{2}+$ $\mathrm{dNH}_{3}+\mathrm{eH}_{2} \mathrm{~S}$

\subsubsection{Asumsi-asumsi}

Beberapa asumsi yang digunakan dalam penelitian ini adalah:

- Lindi yang dihasilkan dari Skenario 1 ditentukan berdasarkan 25\% moisture content dan 15\% air hujan yang masuk ke dalam timbunan sampah. 
- Data transportasi dari sumber ke bank sampah dan penggunaan bahan bakar untuk pembakaran sampah tidak masuk dalam perhitungan karena pengangkutan sampah menggunakan gerobak.

Data inventory (input maupun output) dari tiga skenario yang digunakan disajikan secara lengkap pada Tabel 2 dan Tabel 3.

Tabel 2. Data inventory (input).

\begin{tabular}{ll}
\hline Skenario & Data input (kg/bulan) \\
\hline Penimbunan sampah keseluruhan & Sampah layak jual (SLJ): \\
Pembakaran sampah terbuka & Kantong plastik $=163.29$ \\
(open burning) & Botol plastik $=23.45$ \\
Bank sampah dan penimbunan & Kertas $=109.98$ \\
sampah organik terbuka & Karet $=5,125$ \\
& Logam $=11.96$ \\
& Organik $=926.58$ \\
\hline
\end{tabular}

Tabel 3. Data inventory (output).

\begin{tabular}{|c|c|c|}
\hline Skenario & $\mathrm{D}$ & \\
\hline \multirow{5}{*}{$\begin{array}{l}\text { Penimbunan sampah } \\
\text { keseluruhan }\end{array}$} & $\mathrm{CH}_{4}$ & $199,77 \mathrm{~kg} /$ bulan \\
\hline & $\mathrm{CO}_{2}$ & $335,66 \mathrm{~kg} /$ bulan \\
\hline & $\mathrm{NH}_{3}$ & $6,84 \mathrm{~kg} /$ bulan \\
\hline & $\mathrm{H}_{2} \mathrm{~S}$ & $1,46 \mathrm{~kg} /$ bulan \\
\hline & Lindi & 230,10 liter/bulan \\
\hline \multirow{6}{*}{$\begin{array}{l}\text { Pembakaran sampah } \\
\text { terbuka (open burning) }\end{array}$} & $\mathrm{CH}_{4}$ & $7,89 \mathrm{~kg} /$ bulan \\
\hline & $\mathrm{CO}_{2}$ & $597,81 \mathrm{~kg} /$ bulan \\
\hline & $\mathrm{N}_{2} \mathrm{O}$ & $0,1 \mathrm{~kg} /$ bulan \\
\hline & LHV & \\
\hline & Residu & $99,86 \mathrm{~kg} /$ bulan \\
\hline & Logam & $11,96 \mathrm{~kg} / \mathrm{bulan}$ \\
\hline \multirow{18}{*}{$\begin{array}{l}\text { Bank sampah dan } \\
\text { penimbunan sampah } \\
\text { organik terbuka }\end{array}$} & Timbunan sampah: & \\
\hline & $\overline{\mathrm{CH}_{4}}$ & $73,45 \mathrm{~kg} /$ bulan \\
\hline & $\mathrm{CO}_{2}$ & $170,04 \mathrm{~kg} /$ bulan \\
\hline & $\mathrm{NH}_{3}$ & $5,63 \mathrm{~kg} /$ bulan \\
\hline & $\mathrm{H}_{2} \mathrm{~S}$ & $1,10 \mathrm{~kg} /$ bulan \\
\hline & Lindi & 207,54 liter/bulan \\
\hline & $-\mathrm{BOD}_{5}{ }^{*}$ & $10.000 \mathrm{mg} / \mathrm{l}$ \\
\hline & - $\mathrm{COD}^{*}$ & $18.000 \mathrm{mg} / \mathrm{l}$ \\
\hline & - TOC $^{*}$ & $6.000 \mathrm{mg} / \mathrm{l}$ \\
\hline & - Nitrat* & $25 \mathrm{mg} / \mathrm{l}$ \\
\hline & Bank sampah: & \\
\hline & Kantong plastik & Rp 500/kg \\
\hline & Gelas plastik & $\mathrm{Rp} 3.000 / \mathrm{kg}$ \\
\hline & Ember plastik & $\mathrm{Rp} 2.000 / \mathrm{kg}$ \\
\hline & Kertas kecil & $\mathrm{Rp} 1.500 / \mathrm{kg}$ \\
\hline & Kertas kardus & $\mathrm{Rp} 600 / \mathrm{kg}$ \\
\hline & Buku bekas & $\mathrm{Rp} 1.500 / \mathrm{kg}$ \\
\hline & Karet & $\mathrm{Rp} 700 / \mathrm{kg}$ \\
\hline
\end{tabular}




\begin{tabular}{lrr}
\hline Skenario & Data output \\
\hline & Logam kaleng & $\mathrm{Rp} 1.500 / \mathrm{kg}$ \\
& Aluminium & $\mathrm{Rp} 10.000 / \mathrm{kg}$ \\
& Besi & $\mathrm{Rp} \mathrm{3.000/ \textrm {kg }}$ \\
\hline
\end{tabular}

*Sumber: Tchobanoglous and Kreith (2019).

\section{HASIL DAN PEMBAHASAN}

Fase terakhir dalam studi Life Cycle Assessment adalah Impact Assessment menggunakan metode CML Baseline v.v4. Potensi dampak yang dibahas adalah pemanasan global (dalam satuan $\mathrm{kg} \mathrm{CO}_{2}$ ekuivalen).

\subsection{Life cycle impact assessment dan interpretasi}

Berdasarkan Tabel 4, Skenario 3 menghasilkan potensi pemanasan global lebih rendah dari pada Skenario 1 dan 2 (S3 $<$ S2 $<$ S1). Kegiatan bank sampah yang didahului dengan pemilahan sampah oleh masyarakat menjadi SLJ $(25,30 \%)$ dan STJ $(74,70 \%)$ dapat mengurangi potensi dampak pemanasan global. Optimalisasi pemilahan sampah juga dapat menurunkan potensi asidifikasi dan pembentukan ozon lebih dari dua kali lipat (Bernstad et al. 2011). Pemilahan sampah dapat menurunkan timbulan sampah yang ditimbun di lahan terbuka. Skenario 3 sudah diterapkan di $105 \mathrm{KK}$ atau sekitar 4,3\% dari total $2445 \mathrm{KK}$. Apabila diterapkan di seluruh masyarakat dengan asumsi komposisi sampah yang dihasilkan sama, maka reduksi timbulan sampah mencapai 24,8 ton/bulan. Total pendapatan dari bank sampah mencapai Rp 27.241.979 setiap bulannya.

Tabel 4. Potensi dampak pemanasan global.

\begin{tabular}{cccc}
\hline LCIA & Skenario 1 & Skenario 2 & Skenario 3 \\
\hline Potensi pemanasan global & $13,057 \mathrm{~kg} \mathrm{CO}_{2}$ eq. & $10,850 \mathrm{~kg} \mathrm{CO}_{2}$ eq. & $6,395 \mathrm{~kg} \mathrm{CO}_{2}$ eq. \\
\hline
\end{tabular}

Skenario 1 yang merupakan penimbunan sampah secara terbuka menghasilkan potensi dampak pemanasan global paling tinggi. Potensi dampak tidak terjadi secara cepat, melainkan berlangsung lama akibat masih tercampurnya sampah yang mudah dan sulit terdekomposisi. Sampah organik akan terdekomposisi kurang dari 5 tahun, sedangkan sampah karet, plastik dan logam akan lebih lama, bahkan tidak dapat terdekomposisi (Tchobanoglous and Kreith 2019). Pada Skenario 3, hanya sampah organik saja yang ditimbun secara terbuka karena didahului oleh pemilahan sampah, sedangkan untuk sampah yang sulit terdegradasi dikelola oleh bank sampah. Potensi dampak pemanasan global dari Skenario 3 lebih rendah 87,6\% daripada Skenario 1. Berdasarkan Gambar 4, kontributor potensi dampak pada Skenario 1 dan Skenario 3 adalah metana $\left(\mathrm{CH}_{4}\right)$ dan karbon dioksida $\left(\mathrm{CO}_{2}\right)$ yang dihasilkan dari proses dekomposisi sampah. Di samping itu, hidrogen sulfida $\left(\mathrm{H}_{2} \mathrm{~S}\right)$ dan amonia $\left(\mathrm{NH}_{3}\right)$ juga dihasilkan, tetapi tidak berkontribusi besar. 


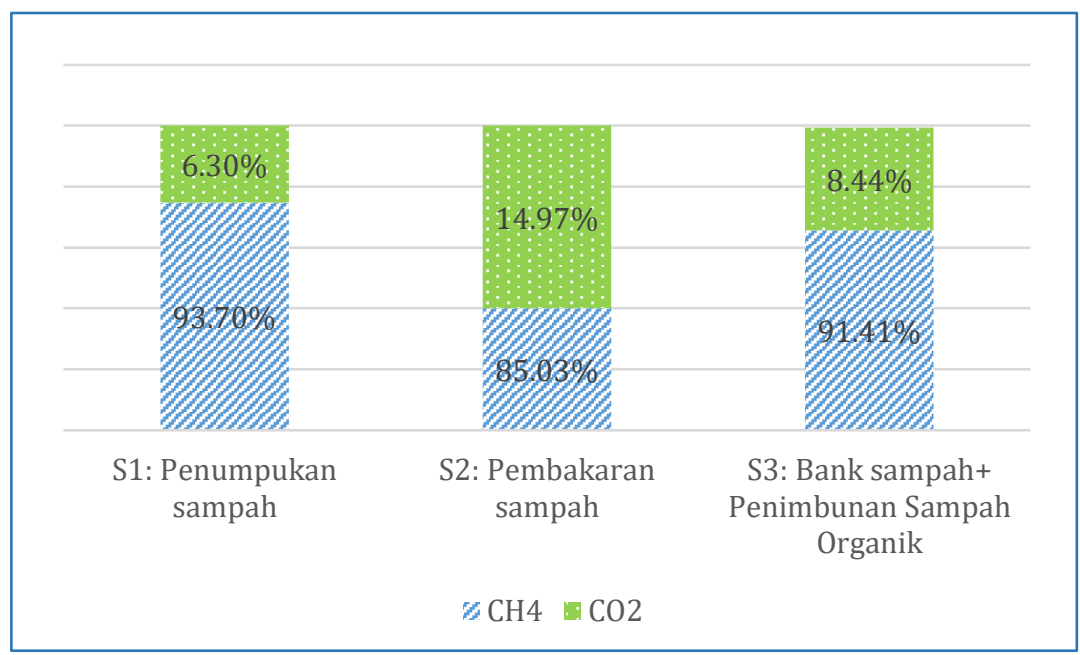

Gambar 4. Kontributor dampak potensi pemanasan global.

Penelitian lain menunjukkan bahwa open dumping merupakan bentuk penanganan sampah yang paling tinggi menimbulkan pemanasan global karena tidak adanya penanganan gas (Saheri et al. 2012; Babu et al. 2014). Gas hasil dekomposisi seperti $\mathrm{CO}_{2}, \mathrm{CH}_{4}, \mathrm{H}_{2} \mathrm{~S}$ dan $\mathrm{NH}_{3}$ yang terlepas ke atmosfer tanpa penanganan berpotensi meningkatkan potensi pemanasan global. Disamping itu, open dumping juga menghasilkan lindi yang mengandung polutan seperti BOD 5 , COD, nitrat, dsb. yang berpotensi mencemari lingkungan sekitar. Potensi dampak yang dapat ditimbulkan dari lindi tersebut adalah eutrofikasi. Dampak lain yang ditimbulkan dari dekomposisi sampah yaitu potensi asidifikasi karena terlepasnya emisi $\mathrm{NH}_{3}$ ke atmosfer (Tabel 5).

Tabel 5. Potensi dampak lingkungan lainnya.

\begin{tabular}{|c|c|c|}
\hline Skenario 1 & Skenario 2 & Skenario 3 \\
\hline Eutrofikasi & Human toxicity & Eutrofikasi \\
\hline $0,0078 \mathrm{~kg} \mathrm{PO}_{4} \mathrm{eq}$. & 0,00240 kg 1,4-dicholorobenzene & $0,01385 \mathrm{~kg} \mathrm{PO}_{4}$ eq. \\
\hline Kontributor: & Kontributor: & Kontributor: \\
\hline $\mathrm{NH}_{3}: 74,87 \%$ & $\mathrm{SO}_{2}: 100 \%$ & COD: $54,29 \%$ \\
\hline COD: $25,12 \%$ & & $\mathrm{NH}_{3}: 45,70 \%$ \\
\hline Asidifikasi & Asidifikasi & Asidifikasi \\
\hline $0,026 \mathrm{~kg} \mathrm{SO}_{2}$ eq. & $0,0225 \mathrm{~kg} \mathrm{SO} 2$ eq. & $0,02870 \mathrm{~kg} \mathrm{SO}_{2}$ eq. \\
\hline Kontributor: & Kontributor: & Kontributor: \\
\hline $\mathrm{NH}_{3}: 100 \%$ & $\mathrm{SO}_{2}: 100 \%$ & $\mathrm{NH}_{3}: 100 \%$ \\
\hline
\end{tabular}

Skenario 2 yang merupakan pembakaran sampah secara terbuka juga menghasilkan gas seperti $\mathrm{CO}_{2}, \mathrm{CH}_{4}$ dan $\mathrm{N}_{2} \mathrm{O}$ yang dapat terlepas ke atmosfer. Di samping itu, ada potensi dampak asidifikasi dan human toxicity akibat pelepasan emisi sulfur dioksida ( $\mathrm{SO}_{2}$ ). Menurut Magazzino et al. (2020), sampah plastik dan karet mengandung senyawa beracun seperti logam berat dan Polychlorinated 
Biphenyls (PCB) apabila dibakar secara terbuka dan tanpa pengendalian emisi. Pembakaran tidak sempurna dari plastik menghasilkan senyawa karsinogenik yang berbahaya saat terhirup (Verma et al. 2016). Pembakaran sampah di Desa Sokosari terjadi secara sporadis oleh masyarakat di banyak tempat.

Merujuk pada Faaij (2004), sampah di Desa Sokosari berpotensi menghasilkan energi apabila dimanfaatkan sebagai sumber energi panas lower heating value (LHV) sebesar 18,35 MJ/kg. Nilai ini sesuai untuk bahan bakar substitusi batu bara yang biasanya berkisar $>2.500 \mathrm{kkal} / \mathrm{kg}$ atau $10,46 \mathrm{MJ} / \mathrm{kg}$. Pemanfaatan sampah menjadi bahan bakar refuse derived fuel (RDF) yang sejalan dengan program waste to energy (WTE) di Kabupaten Tuban dapat menambah nilai ekonomi sampah hingga Rp 30.000/kg. Perlu penanganan tambahan untuk dapat menghasilkan RDF yang sesuai dengan kebutuhan industri semen, misalnya kandungan air harus $<50 \%$ (Xin et al. 2020). Komposisi sampah yang didominasi oleh sampah sisa makanan, sampah dapur dan sampah pekarangan atau kebun berpotensi menghasilkan kandungan air yang tinggi. Pemilahan sampah dari sumber sampah atau setiap rumah penduduk dapat sangat membantu mengurangi kandungan air sampah.

\subsection{Potensi pemrosesan lebih lanjut menjadi RDF dan kompos}

Salah satu potensi yang dapat dilakukan adalah dengan mengolah sampah lebih lanjut menjadi produk lain seperti RDF dan kompos. Berbeda dengan pra studi kelayakan pembangunan RDF plant di Kabupaten Tuban yang direncanakan mengolah sampah tercampur yang ada di TPA sampah, konversi sampah ini berasal dari sumber sampah yang tidak tercampur antara sampah organik (STJ) dan non-organik (SLJ), sehingga kandungan air pada sampah non organik menjadi lebih rendah, tidak tercampur dengan tanah dan prosesnya lebih sederhana tanpa pemilahan pendahuluan.

Secara umum, RDF dihasilkan dengan melakukan pengolahan sampah menggunakan alat magnetic separator, trammel screen, shredder dan mill (Caputo and Pelagagge 2002). Kondisi sampah pada nyatanya sudah terpilah ketika masuk ke bank sampah, sehingga dalam pembuatan RDF hanya diperlukan shredder untuk mencacah sampah non organik sampai ukuran $<50$ mm menjadi RDF jenis fluff. Jenis shredder yang dapat digunakan yaitu shredder machine V600 single shaft (PT Power Machine International 2020). Berdasarkan data karakteristik sampah (Tabel 1), kandungan air sampah memenuhi syarat untuk diolah menjadi kompos (44-64\%) (Kadir et al. 2016). Pengomposan dapat dilakukan secara mesofilik dalam anaerobic digestion (AD). Teknologi AD merupakan teknologi paling ramah lingkungan, memiliki keandalan operasional, berpotensi menghasilkan biogas dan prosesnya berlangsung secara tertutup (AlRumaihi et al. 2020). 
Pengelolaan sampah Skenario 3 yang menghasilkan potensi dampak pemanasan global paling rendah adalah pengolahan SLJ menjadi RDF dan STJ menjadi kompos dengan nilai $0,089 \mathrm{~kg} \mathrm{CO} 2$ eq. dari setiap $1 \mathrm{~kg}$ sampah yang dikelola (Gambar 5). Data inventory (input dan output) untuk dua pilihan pengolahan dengan potensi dampak paling rendah tersebut tersaji pada Tabel 6. Produk biogas yang dihasilkan berpotensi dimanfaatkan lebih lanjut sebagai sumber energi pengganti listrik. Namun, masih diperlukan penelitian lebih lanjut untuk mengetahui kecocokan penggunaan biogas sebagai pengganti listrik.

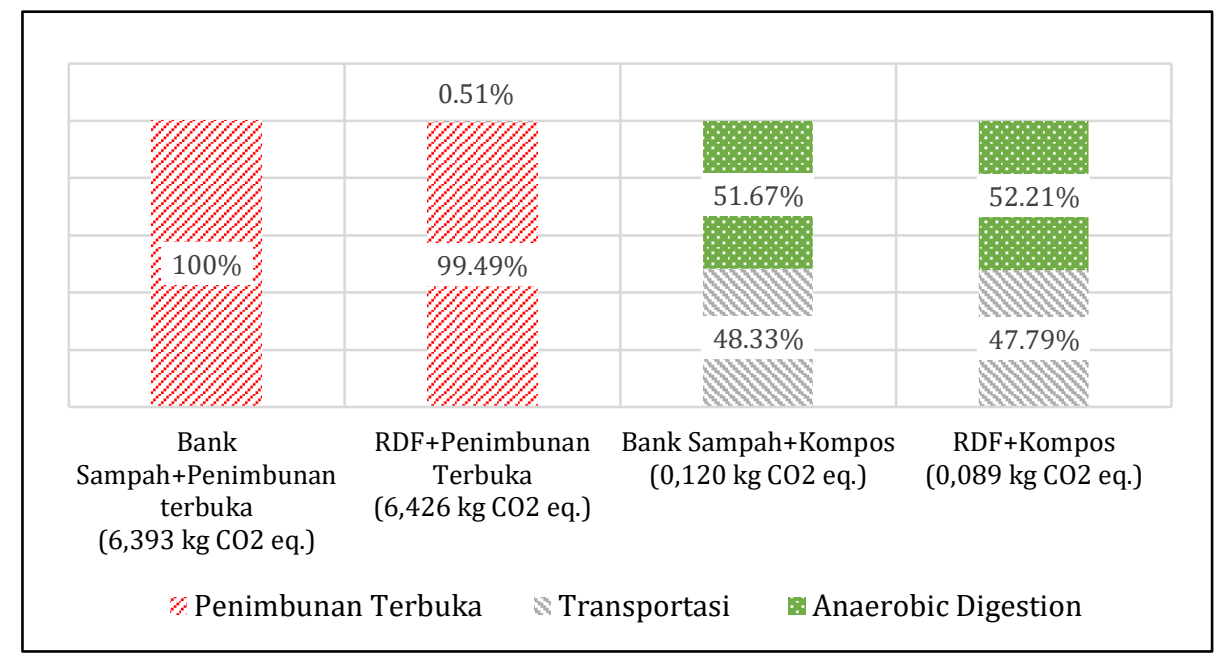

Gambar 5. Potensi dampak pemanasan global (kg $\mathrm{CO}_{2}$ eq.) dari skenario pengelolaan sampah lanjutan dan kontributor dampak.

Tabel 6. Data inventory pengolahan SLJ menjadi RDF dan STJ menjadi kompos.

\begin{tabular}{|c|c|c|c|c|c|c|}
\hline $\begin{array}{l}\text { Pilihan } \\
\text { pengolahan }\end{array}$ & Input & Jumlah & Unit & Output & Jumlah & Unit \\
\hline \multirow{3}{*}{$\begin{array}{l}\text { SLJ } \\
\text { menjadi } \\
\text { RDF }\end{array}$} & SLJ & 313,82 & $\mathrm{~kg}$ & RDF & 30.000 & $\mathrm{Rp} / \mathrm{kg}$ \\
\hline & Listrik & 48,30 & $\mathrm{kWh}$ & $\begin{array}{l}\text { **Emisi listrik: } \\
\mathrm{CO}_{2}\end{array}$ & 0,862 & ton/MWh \\
\hline & $\begin{array}{l}\text { Transportasi } \\
\text { ke pabrik } \\
\text { semen }\end{array}$ & $313,82 * 44,10$ & $\mathrm{~kg}^{*} \mathrm{~km}$ & $\begin{array}{l}* * * \text { Emisi solar: } \\
{ }^{*} \mathrm{CO}_{2}\end{array}$ & 2,22 & $\mathrm{~kg} / \mathrm{l}$ \\
\hline \multirow{7}{*}{$\begin{array}{l}\text { *STJ } \\
\text { menjadi } \\
\text { kompos }\end{array}$} & STJ & 926,58 & $\mathrm{~kg}$ & Kompos & 15.000 & $\mathrm{Rp} / \mathrm{kg}$ \\
\hline & & & & $\begin{array}{l}\text { Emisi produksi } \\
\text { kompos: }\end{array}$ & & \\
\hline & & & & $\mathrm{CH}_{4}$ & 776,28 & $\mathrm{~g}$ \\
\hline & & & & $\mathrm{N}_{2} \mathrm{O}$ & 90,79 & $\mathrm{~g}$ \\
\hline & & & & $\mathrm{NH}_{3}$ & 263,15 & g \\
\hline & Listrik & 40,02 & $\mathrm{kWh}$ & $\begin{array}{l}\text { Emisi Listrik: } \\
{ }^{* *} \mathrm{CO}_{2}\end{array}$ & 0,862 & ton/MWh \\
\hline & Air & 0,5 & ton & Biogas & 138,99 & $\mathrm{~m}^{3}$ \\
\hline
\end{tabular}

Sumber: *Al-Rumaihi et al. (2020); ${ }^{* *}$ Kementerian ESDM (2016); ${ }^{* * *}$ IPCC (1998); Ummatin et al. (2019); dan hasil analisis. 


\subsection{Rekomendasi}

Rekomendasi untuk meminimalkan potensi dampak lingkungan adalah dengan meningkatkan nilai jual sampah hasil bank sampah dengan cara konversi sampah menjadi RDF dan meningkatkan upaya pemilahan sampah dari sumbernya. Produk RDF berpotensi sebagai bahan bakar alternatif industri semen di Kabupaten Tuban. Peningkatan nilai jual sampah juga berpotensi meningkatkan antusiasme masyarakat dalam memilah sampah karena keuntungan menjual sampah lebih tinggi. Upaya pemilahan sampah dari sumbernya harus disertai dengan edukasi untuk meningkatkan kesadaran masyarakat terhadap pemilahan sampah. Masyarakat pedesaan masih terbatas dalam hal informasi penanganan sampah. Pemilahan sampah dari sumber yang dilakukan masyarakat akan membantu meringankan proses konversi sampah menjadi RDF dan kompos.

\section{KESIMPULAN DAN SARAN}

Life Cycle Assessment (LCA) dapat digunakan untuk menghitung dan membandingkan potensi dampak lingkungan dari tiga jenis penanganan sampah di lingkungan pedesaan. Meskipun baru diterapkan pada sebagian kecil kepala keluarga, bank sampah mampu berkontribusi dalam mengurangi potensi dampak pemanasan global. Setiap $1 \mathrm{~kg}$ sampah yang dikelola oleh bank sampah menghasilkan potensi dampak pemanasan global lebih rendah dibandingkan dengan sistem penimbunan dan pembakaran sampah yakni sebesar $6,395 \mathrm{~kg} \mathrm{CO}_{2}$ eq. Pengelolaan sampah lebih lanjut oleh bank sampah dapat dilakukan dengan material recovery dan peningkatan nilai ekonomi sampah. Konversi sampah layak jual menjadi RDF dan sampah tidak layak jual menjadi kompos dapat menurunkan lagi potensi dampak menjadi $0,089 \mathrm{~kg} \mathrm{CO}_{2}$ eq. untuk setiap $1 \mathrm{~kg}$ sampah yang dikelola.

\section{UCAPAN TERIMAKASIH}

Penulis mengucapkan terima kasih kepada Bank Sampah Asoka Berseri, Kepala Dusun dan warga RT 01 RW 02 Desa Sokosari yang telah membantu dan bekerja sama dalam pengambilan data penelitian.

\section{DAFTAR PUSTAKA}

Abbas II, Chaaban JK, Shaar AA and Al-Rabaa AR. 2017. Solid waste management in Lebanon : challenges and recommendations. Journal of Environment and Waste Management 4(2):53-63.

Abeliotis K. 2011. Life cycle assessment in municipal solid waste management. In: Kumar S. Integrated Waste Management Vol. I. IntechOpen. London. 
https://doi.org/10.5772/698.

Achinas S and Euverink GJW. 2016. Theoretical analysis of biogas potential prediction from agricultural waste. Resource-Efficient Technologies 2(3):143-147. https://doi.org/10.1016/j.reffit.2016.08.001.

Al-Rumaihi A, McKay G, Mackey HR and Al-Ansari T. 2020. Environmental impact assessment of food waste management using two composting techniques. Sustainability 12(4):1-23. https://doi.org/10.3390/su12041595.

Babu GLS, Lakshmikanthan P and Santhosh LG. 2014. Life cycle analysis of municipal solid waste (MSW) land disposal options in Bangalore City [Proceeding]. International Conference on Sustainable Infrastructure 2014 795-806. https://doi.org/10.1061/9780784478745.075.

Bailie RC, Everett JW, Liptak BG, Liu DHF, Rugg FM and Switzenbaum MS. 1999. Solid Waste. CRC Press. Boca Raton.

Bernstad A, Jansen JLC and Aspegren H. 2011. Life cycle assessment of a household solid waste source separation programme: a Swedish case study. Waste Management \& Research 29(10):1027-1042. https://doi.org/10.1177/0734242X11406170.

[BPS] Badan Pusat Statistik Kabupaten Tuban. 2019. Kecamatan Soko dalam angka 2019. BPS Kabupaten Tuban. Tuban.

Budihardjo MA, Wahyuningrum IFS, Muhammad FI and Pardede R. 2019. The role of waste banks in the reduction of solid waste sent to landfill in Semarang, Central Java, Indonesia. IOP Conference Series: Earth and Environmental Science 337 012028. https://doi.org/10.1088/17551315/337/1/012028.

Caputo AC and Pelagagge PM. 2002. RDF production plants: I design and costs. Applied Thermal Engineering 22(4):423-437. https://doi.org/10.1016/ S1359-4311(01)00100-4.

[EPA] Environmental Protection Agency. 2001. Emission inventory improvement program [internet]. Tersedia di: https://www.epa.gov/sites /production/files/2015-08/documents/i01.pdf.

Faaij APC. 2004. Biomass combustion. Encyclopedia of Energy 1:175-191. https://doi.org/10.1016/B0-12-176480-X/00355-7.

[IPCC] Intergovernmental Panel on Climate Change. 1998. Good practice guidance and uncertainty management in national greenhouse gas inventories. IGES. Hayama.

[IPCC] Intergovernmental Panel on Climate Change. 2006. 2006 IPCC guidelines for national greenhouse gas inventories volume 5 waste. Eds. National Greenhouse Gas Inventories Programme, Eggleston HS, Buendia L, Miwa K, Ngara T and Tanabe K. IGES. Hayama.

Kadir AA, Azhari NW and Jamaludin SN. 2016. An overview of organic waste in 
composting. MATEC Web of Conferences 47 05025: https://doi.org/10.1051/matecconf/20164705025.

[Kementerian ESDM] Kementerian Energi dan Sumber Daya Mineral. 2016. Faktor emisi GRK sistem interkoneksi tenaga listrik tahun 2016 [internet]. Tersedia

http://jcm.ekon.go.id/en/uploads/files/DocumentJCM/Rules\&Guidelines /Emission_Factor_DJK_ESDM_2016.pdf.

Komilis D and Athiniotou A. 2014. A water budget model for operating landfills: an application in Greece. Waste Management \& Research 32(8):717-725. https://doi.org/10.1177/0734242X14545505.

Liamsanguan C and Gheewala SH. 2008. LCA: a decision support tool for environmental assessment of MSW management systems. Journal of Environmental Management 87(1):132-138. https://doi.org/10.1016/j. jenvman.2007.01.003.

Luong ND, Giang HM, Thanh BX and Hung NT. 2013. Challenges for municipal solid waste management practices in Vietnam. Waste Technology 1(1):1721. https://doi.org/10.12777/wastech.1.1.2013.17-21.

Magazzino C, Mele M and Schneider N. 2020.The relationship between municipal solid waste and greenhouse gas emissions: evidence from Switzerland. Waste Management 113:508-520. https://doi.org/10.1016/j.wasman. 2020.05.033.

Pambudi YS, Purnama Y, Dwijendra NKA, Kholifah S and Caniago A. 2020. The effect of internal factors on the improvement of the role of the community and quality of waste bank management "Mekar Asri" in RT. 5 RW. XVI, Mojosongo Sub-District, Surakarta City, Indonesia. Test Engineering and Management 82:14695-14703.

Phyllis2. 2020. Database for the physico-chemical composition of (treated) lignocellulosic biomass, micro- and macroalgae, various feedstocks for biogas production and biochar [internet]. Tersedia di: https://phyllis.nl/ Browse/Standard/ECN-Phyllis.

PT Power Machine International. 2020. Shredder machine V600 single shaft [internet]. Tersedia di: https://www.powermachineint.com/mesinshredder-plastik.

Saheri S, Mir MA, Basri NEA, Mahmood NZB and Begum RA. 2012. Life cycle assessment for solid waste disposal options in Malaysia. Polish Journal of Environmental Studies 21(5):1377-1382.

Suardi LR, Gunawan B, Arifin M and Iskandar J. 2018. A review of solid waste management in waste bank activity problems. International Journal of Environment, Agriculture and Biotechnology 3(4):1518-1526. https://doi. org/10.22161/ijeab/3.4.49. 
Tchobanoglous G and Kreith F. 2019. Handbook of solid waste management 2nd Ed. McGraw-Hill Companies. New York.

Ummatin KK, Wiratno SE, Nurminasih S, Rahmat A and Faria N. 2019. Prastudi kelayakan pembangunan RDF Plant di Kabupaten Tuban [internet]. Tersedia di: http://sippa.ciptakarya.pu.go.id/sippa_online/ws_file/doku men_usulan/ded/ded_d39173d85b99ec13bd3b325d33103f03117c25ad. pdf.

Verma R, Vinoda KS, Papireddy M and Gowda ANS. 2016. Toxic pollutants from plastic waste- a review. Procedia Environmental Sciences 35:701-708. https://doi.org/10.1016/j.proenv.2016.07.069.

Warmadewanthi and Haqq M. 2019. Implementation of waste banks for reduction of solid waste in South Surabaya. MATEC Web of Conferences 276 06021. https://doi.org/10.1051/matecconf/201927606021.

Wijayanti DR and Suryani S. 2015. Waste bank as community-based environmental governance: a lesson learned from Surabaya. Procedia Social and Behavioral Sciences 184:171-179. https://doi.org/10.1016/ j.sbspro.2015.05.077.

Wulandari D, Utomo SH and Narmaditya BS. 2017. Waste bank: waste management model in improving local economy. International Journal of Energy Economics and Policy 7(3):36-41.

Xin C, Zhang T, Tsai SB, Zhai YM and Wang J. 2020. An empirical study on greenhouse gas emission calculations under different municipal solid waste management strategies. Applied Sciences 10(5):1-23. https://doi. org/10.3390/app10051673. 